\title{
The Visegrád Group as a Vehicle for Promoting National Interests in the European Union: The Case of the Czech Republic
}

\author{
MAREK NEUMAN
}

$\frac{\text { DE }}{G} \stackrel{\substack{\text { DE GRUYTER } \\ \text { OPEN }}}{ }$

Politics in Central Europe (ISSN: 1801-3422)

Vol. 13, No. 1

DOI: $10.1515 /$ pce-2016-0022

\begin{abstract}
This contribution asks whether sub-regional integration projects such as the Visegrád Group may be understood as mechanisms for pursuing one Group member's national interests while it stands at the European Union's helm. I assess this question based on the case of the first Visegrád Group member to assume the EU Council presidency: the Czech Republic. Examining three specific policy areas - the reinvention of the EU's Eastern neighbourhood policy; the strengthening of EU energy security; and the incorporation of a stronger human rights and external democratisation approach into EU foreign policy - this case study presents a mixed picture. It confirms the potential of the Visegrád Group to be a vehicle for furthering the national preferences of one Group member while it holds the rotating EU Council presidency. Whether or not this potential is fully realised will depend primarily on the degree to which the interests of the four Visegrád countries converge.
\end{abstract}

Keywords: European Union, Council rotating presidency, Visegrád Group, the Czech Republic, agenda- setting, Eastern Partnership, energy security, human rights, democracy promotion

\section{Introduction}

When in 1991, three countries - Czechoslovakia, Hungary and Poland - formed an informal alliance designed to foster their integration into NATO and EU structures, very few analysts could foresee that twenty-five years later, the

1 The author would like to thank prof. Lyubov Shishelina and two anonymous reviewers for their valuable feedback. 
Visegrád Group (V4) would still be around. While the V4's initial raison d'être was achieved with the accession of its - by then four - members to NATO in 1999 (the Czech Republic, Hungary and Poland) and 2004 (Slovakia) and to the European Union in 2004 (all four countries), the four states decided to cooperate on issues relevant to all of them by exerting influence jointly from within the ranks of NATO and the EU (Dangerfield 2008). In the case of the European Union in particular, the V4's coalition potential has frequently been emphasised since Bratislava, Budapest, Prague and Warsaw regard each other as natural partners on many topics and believe in pursuing certain policies together (Falkowski 2003; Gyárfášová 2003). While these countries are clearly far from being homogeneous and a coordinated approach is barred on a number of issues, the EU's Common Foreign and Security Policy (CFSP) and Common Security and Defence Policy (CSDP) have been highlighted as the areas with the greatest potential for coordination vis-à-vis the European Union. ${ }^{2}$

This article assesses whether the Visegrád Group has indeed capitalised on its potential as a coalition within the realm of EU foreign policy-making. Rather than focusing solely on the negotiation stage of EU foreign policy-making, however it asks whether the V4 may also serve as a vehicle for promoting the national interests of the V4 member that holds the rotating EU Council presidency. Traditionally, the country at the EU's helm has been expected to refrain from advancing its national interests during its six-month long mandate; instead, it should act as an honest broker among the other member states, observing the norms of impartiality, neutrality and efficiency (de Bassompierre 1988; Hayes-Renshaw and Wallace 1997; Schout 1998). More recent accounts of the rotating Council presidency suggest, however, that the presiding country may find numerous ways to alter the EU's political agenda by way of its agenda-setting, agenda-structuring and agenda-excluding powers (Elgström 2006; Princen 2007; Schalk et al 2007; Tallberg 2003). This article aligns itself with this more recent understanding of the rotating Council presidency, adopting Tallberg's (2003) argument that the presiding member state is a strategic actor "seeking to satisfy national preferences within the confines of [its] formally delegate role" (p. 5). The question that, thus, arises is whether regional integration efforts such as the Visegrád Group can (at least partially) override the formal requirement of diminished agency of the member state that holds the rotating presidency.

The first V4 member state to hold the Council presidency was the Czech Republic, which performed this role in the first half of 2009. It is, thus, the Czech state that forms the focus of this study. To answer the question of whether - and how - the Czech Republic made use of the V4 to further its own national foreign

2 "Declaration of the Prime Ministers of the Czech Republic, the Republic of Hungary, the Republic of Poland and the Slovak Republic on the Cooperation of the Visegrád Group Countries after their Accession to the European Union," available at http://www.visegradgroup.eu/documents/visegrad-declarations/ visegrad-declaration-110412-1 (accessed 12 November 2016) 
policy preferences, this contribution proceeds as follows ${ }^{3}$ : after briefly discussing the priorities of the Czech presidency, it turns to three empirical areas and assesses whether the V4 served as a vehicle for installing Prague's preferences at supranational EU level. Moreover, it explores whether the Czech Republic subsequently tapped into the V4's coalition potential when negotiating specific policies in Brussels. This research article adopts the methodology of a qualitative case study. In this regard, each area of inquiry is structured so as to determine the relationship between the Czech Republic and the other V4 countries both before the Czech Republic's Council presidency and during the presidency itself. To improve analytical clarity, each inquiry also has a similar structure: it first examines the rationale behind the forming of a (national) preference vis-à-vis the V4 and then addresses the promotion of that preference (possibly in conjunction with the V4) before concluding with a brief overview of the Brussels-based negotiations (by, with or without the V4). To pursue this methodology, I traced the relevant processes out in detail. This work was enabled by both primary and secondary literature research and supported by the conducting of some thirty (30) semi-structured interviews. The interviewees were drawn predominantly from a pool of Czech policy-makers based in Prague or in EU institutions in Brussels. To remedy any possible bias associated with interviewing policy-makers from one member state only, I also conducted interviews with policy officers from other member states, most of whom were located in Brussels. Aside from these first-hand participants in foreign policy-making within EU institutions, several interviewees were representatives of the civil society or academic sectors either in the Czech Republic or other EU member states. To preserve anonymity where required, the interviewees are identified in this study by way of letters (e.g. A, B, etc.). Ultimately, this comprehensive approach allows me to answer the main research question, i.e. whether the Visegrád Group may be understood as a mechanism for pursuing national preferences while one V4 state holds the rotating EU Council presidency. ${ }^{4}$

\section{The Czech Republic's Council Presidency}

Prague started to prepare for its Council presidency in 2007, that is, some one-and-a-half years before assuming the EU helm on 1 January 2009. This preparation was not limited to the strengthening of bureaucratic capacities and consisted largely of the formulating of a coherent work programme that would

3 For a more detailed analysis of the Czech Republic's integration efforts in Central Europe in general and within the Visegrád Group in particular, please refer to Waisová (2011).

4 While at first sight this question may appear less relevant in the post-Lisbon era given the introduction of a permanent president of the Foreign Affairs Council (High Representative of the European Union for Foreign Affairs and Security Policy), the complex nature of EU foreign policy-making leaves much room for input from the rotating Council presidency. In particular, the rotating president still presides over all of the working groups of the Council of Ministers, including COREPER I and II and COPS. 
define the Czech Council presidency. The outcome of this all-encompassing domestic deliberation process was a programme whose theme, "Europe without Barriers" outlined the presidency's three main priorities: the economy, energy and the European Union's role in the world. ${ }^{5}$ In economic terms, the Czech Republic aspired to promote a free market economy and steer against the protectionist measures that could prove very popular with some individual EU member states at a time when the EU financial crisis was in full swing. From an energy perspective, Prague sought to strengthen the EU's energy security, an issue it took to be increasingly pressing given the 2006 Russia-Ukraine energy crisis. Regarding the third priority - the EU's position in the world - the Czechs aimed to tap into their own transition experience and promote transition processes in the EU's immediate neighbourhood in the east.

Most of this Czech presidency preparation period coincided with the country's occupancy of the Visegrád Group's rotating presidency. Standing at the V4 helm in the period between June 2007 and June 2008, the Czech Republic, thus, had the opportunity to test the responsiveness of its closest partners when it came to the Czech EU Council presidency's priorities. It soon became clear that the four V4 countries had established common ground on the topics highlighted by the Czech Ministry of Foreign Affairs (MFA) along with the importance of promoting democracy and human rights in the EU's immediate vicinity. ${ }^{6}$ This last point, while not specifically mentioned in the Czech Republic's EU Council work programme, was nonetheless central to Prague's foreign policy. In fact, human rights promotion and external democratisation may at first glance seem an odd concern for the Czech state given the constraining effects that frequent references to human rights and democracy abuses may have on the fulfilment of other Czech foreign policy goals. Nevertheless, for Prague, this issue remained paramount. According to Gabriela Dlouhá, the former director of the MFA's Department of Human Rights and Transformation Policies, the emphasis that Czech foreign policy put on these concepts was not only normative but also instrumental to all of the country's foreign policy interests. ${ }^{7}$ The Czech Republic promoted human rights, she notes, not because "we are incorrigible idealists or battered dreamers, but because these are a part of the world's legal structure" 8 and, as such, represent the very foundations of prosperity.

These three foreign policy issues - the reinvention of the European Union's policy on the East European neighbourhood; the strengthening of EU energy security; and the incorporation of a stronger human rights and external

5 "Work Programme of the Czech Presidency: Europe without Barriers," available at http://www.eu2009. cz/assets/news-and-documents/news/cz-pres_programme_en.pdf (accessed 20 November 2016)

6 "Czech Presidency of the Visegrad Group (June 2007-June 2008)," available at http://www.visegradgroup. eu/documents/presidency-programs/2007-2008-czech-110412 (accessed 18 November 2016)

7 "Interview B," (Prague: Ministry of Foreign Affairs, 2010)

8 "Interview B," (Prague: Ministry of Foreign Affairs, 2010) 
democratisation dimension into EU foreign policy - take centre stage for the remainder of this study. While Prague evidently agreed with its V4 partners about the need to promote these goals at supranational level, it remains to be seen whether the Visegrád Group served as a vehicle for promoting these preferences and advancing them during the policy negotiations. The implication here is that relying on a regional integration framework within the European Union might enable a presidency-holding country to bypass the rather stringent rules associated with the rotating Council presidency, and in particular, the requirement that the president act as an honest and neutral broker. The Czech Republic arguably took the first step towards such an outcome in 2007 when it pleaded for stronger communication among the V4 actors in Brussels in order to coordinate positions on "virtually all important European issues" (Kořan 2010: 117). Yet, while this may be seen as proof that Prague wanted to ensure that the Visegrád Group was active when it came to take the EU's helm, it remains unclear whether it succeeded in this regard, i.e. whether the Czech Republic's national preferences were - ultimately - pursued in the EU while, at the same time, it acted as an honest broker among the other member states. It is to these questions that I now want to turn.

\section{The Visegrád Group's Role in Furthering the Czech Republic's Interests}

\section{Reinventing the European Union's Eastern Neighbourhood Policy}

The Czech Republic has long seen the 2004 European Neighbourhood Policy, which groups together countries at the Southern (Mediterranean) and Eastern European borders, as an inefficient tool for comprehensively structuring the EU's relationships, including especially the ties with Eastern European countries (Stř́tecký 2008). Consequently, it came as no surprise that when Prague was presented with the opportunity to outline its foreign policy priorities in the lead-up to its EU Council presidency, a new approach to Eastern Europe figured prominently on its agenda. The Visegrád Group was instrumental in the success of these Czech endeavours, assisting both in the formulating of the new approach and its promotion in Brussels. In terms of formulating the Czech Republic's objectives, the Prague Security Studies Institute joined with multiple think-tanks from the other V4 countries to launch the project "Strengthening the Central European Contribution to the Eastern Dimension of EU's CFSP." Spanning a three-year period (2006-2008), this project was intended to:

creat [e] a platform for think-tanks, NGOs and policymakers of Visegrad countries [...] in order to bring new impulses to public and expert debates concerning the Eastern dimension of the Common Foreign and Security Policy, and 
to increase and sustain their role in shaping the political agenda of the European Council, European Commission, [and] European Parliament (Schneider 2008, emphasis added).

More specific ideas about how to facilitate a closer relationship with the EU's eastern neighbours were presented in several policy briefs and during three high-level policy conferences and biannual seminars. Along with a large number of more analytical documents about the East European neighbourhood compiled by third sector think-tanks and non-governmental organisations, the output of this consortium was circulated among MFA civil servants. As such, it served to support the Ministry's efforts to establish a national preference for the EU's approach to its eastern neighbours, which could then be advanced in Brussels for further negotiations.

Once the Czech MFA had prepared its non-paper "ENP and Eastern Neighbourhood - Time to Act: Food for Thought," it turned again to the Visegrád Group for support. In this way, Prague made use of its V4 presidency to call for a more cohesive approach to Eastern Europe:

[t]he goal of the Czech Presidency of the Visegrad Group was to preserve the continuity and tradition of $\mathrm{V} 4$ cooperation while opening it up to new efficient approaches designed to promote mutual understanding, not only among V4 countries but also between EU Member States and the countries in transition neighbouring on the V4 region, especially the countries of Eastern Europe. ${ }^{9}$

By appealing first to the V4, Prague achieved three goals. First, it positioned itself strategically as the initiator of a new EU policy on Eastern Europe - a position generally ascribed to Poland (Kratochvíl 2007: 191-193). Second, it involved all of the other V4 partners - countries generally interested in Eastern Europe - in the issue, thereby improving the standing of this multilateral grouping within the EU institutional system. Third, through the V4's consultations with the three Baltic countries and other important partners such as Germany and Austria, support was garnered for Prague's proposal long before it was officially presented to the EU. Consequently, during a meeting of Visegrád state foreign ministers in April 2008, Prague received the backing of the V4 states to pursue the strategy at EU level: "The Visegrad Group is ready to contribute to the ongoing discussion and effort to strengthen the ENP, which reflects the Group's joint interest in further enhancement of EU relations with the East European countries."10

9 "Activities of the Czech Presidency of the Visegrad Group (June 2007 - June 2008)," available at http:// www.visegradgroup.eu/documents/annual-reports/2007-2008-czech-110412 (accessed 22 November 2016) (emphasis added)

10 "Joint Statement of the Ministers of Foreign Affairs of the Visegrad Group Countries," available at http:// www.visegradgroup.eu/2008/joint-statement-of-the (accessed 22 November 2016) 
With this backing, the Czech Republic continued to promote its new approach to Eastern Europe among the remaining EU countries and within EU institutions; it was quickly joined in this mission by Poland and Sweden, which tabled the more concrete Eastern Partnership proposal. These efforts took place along both formal (institutional) and informal (think-tank and NGO-based) tracks and persuaded the European Commission to publish its own "Communication" document, which endorsed the proposal in late 2008 (Neuman 2015: 120-128). During this lobbying stage, the Czech Republic sought out the support of countries outside the V4 framework, having realised that successful negotiation of the Eastern Partnership during its Council presidency would require a more all-encompassing coalition that went beyond the usual suspects. ${ }^{11}$ What had started as a Czech/V4 effort, thus, became a broadly supported policy initiative, with the result that the Eastern Partnership was negotiated among the EU member states and the six Eastern European partner countries before finally being launched at a Prague summit on 7 May 2009.

\section{Strengthening the European Union's Energy Security}

Ever since the Czech Republic achieved independence in 1993, the country has been wary of its reliance on energy supplies, particularly where Russian sources are concerned. As a result, it invested substantially in linking its oil pipeline system with the Western European one by building the Ingolstadt-Kralupy-Litvínov (IKL) pipeline. Despite the IKL's establishment in 1996, the Czech energy sector continues to be highly vulnerable to market distortions, especially in the case of its natural gas supplies, which all originate in post-Soviet countries.

Having said this, the Czech Republic's reliance on - particularly - Russian natural gas is not unique when we consider the overall state of Central and Eastern European energy dependence; rather, the data shows that this is a feature common to all V4 countries. While it is true that the degree of dependence varies, ${ }^{12}$ all four Visegrád countries are thought to be in a vulnerable position. This vulnerability - combined with limited grid interconnectivity in the region and the perception of Russia as an unreliable energy partner (Neuman 2010) -

11 "Interview C," (Prague: Ministry of Foreign Affairs, 2010)

12 According to a comprehensive comparative study conducted by the EU, the Czech Republic depended on imports for $102 \%$ of its natural gas consumption in 2002; the equivalent figures for Hungary, Poland and Slovakia in this period were $80.6 \%, 66.1 \%$ and $100 \%$, respectively (while a figure of $102 \%$ dependency in the case of the Czech Republic seems rather odd at first sight, it is accurate as it also takes into account the required gas reserves that each country is supposed to have and that are calculated on top of the country's gas consumption as such). This stands in sharp contrast with the result for the EU-15 states, which stood at just $47.8 \%$. Moreover, this dependence of the V4 on natural gas supplies is exacerbated by the fact that almost all (and, in some cases, all) of these gas imports come from the post-Soviet space. For more information, see the data in "Energy, Transport, and Environment Indicators: Data 1992-2002," available at http://ec.europa.eu/eurostat/documents/3930297/5955046/KS-DK-05001-EN.PDF/08df871c-e648-4160-955e-ceaae2b27a24 (accessed 21 November 2016) 
led the Czech Republic to include the strengthening of EU energy security in its Council work programme. For Prague, the saliency of the issue increased with every additional disruption of energy supplies from the east, whether oil or gas was at stake; each delay was seen as a deliberate attempt by the Russian authorities to exert greater influence in the region. As the then Czech Deputy Prime Minister for European Affairs Alexandr Vondra put it:

[the $u$ ]njust manipulation or interruption of energy supplies is as much a security threat as is military action. Post-soviet countries have been experiencing th[is] on a daily basis, as Russia's appetite for using energy as a political tool is growing (Vondra 2007: 1).

During its Council presidency, Prague would focus on diversifying the European Union's energy suppliers, routes and resources. At the same time, it called for the creation of an explicit common external energy plan to complement the European Union's existing internal energy market.

If, as the discussion above suggests, the V4 substantially backed Czech efforts to establish a dedicated Eastern European policy at EU level, then when it came to strengthening EU energy security, the V4's support was overwhelming. This support was further cemented in the wake of the serious Russia-Ukraine crisis in January 2009, at which point between $71 \%$ (Slovakia) and 79\% (Poland) of the population of the V4 states was greatly concerned with their country's energy dependence on Russia (Nosko et al. 2010). As a result, alongside the unilateral promotion of its national preference in Brussels in the pre-Council presidency period, the Czech Republic framed its preference within the larger V4 context, thus making use of the other V4 partners in parallel with its own lobbying efforts. Once again, Prague attempted to build a large coalition of EU member states that would support its quest, falling back upon both formal and informal lobbying mechanisms. When the Czechs set out to negotiate several specific policy changes in Brussels during the first half of 2009, the Visegrád Group's involvement became even more prominent. These negotiations had two central goals: first, they tried to foster explicit EU support for the (then planned) Nabucco pipeline and greater interconnectivity (in both cases backing from the EU budget was sought); and second, they aimed to lay the ground for a transfer of power from member state to EU level so as to establish a common external energy policy in the longer term. As one participant in the negotiations testified, the cooperation among Bratislava, Budapest, Prague and Warsaw evolved to the point that their representatives closely coordinated positions before the meetings themselves. As such, they agreed on both the statements they would make and the order in which they would be presented to other member states, thus confirming the true like-mindedness of the V4 countries 
on energy questions. ${ }^{13}$ In this way, the V4 succeeded in persuading the remaining Central and Eastern European countries and Baltic States to support the Czech Republic's proposals. Even so, they fared considerably worse with the large EU member states, which did not want to jeopardise their long-standing bilateral relations with Moscow. The result was a political compromise: while the EU funded several specific projects intended to enhance grid interconnectivity among - predominantly - Central and Eastern European member states and it even released some (limited) funds for the Nabucco project, there was to be no common EU external energy policy.

\section{Incorporating a Stronger Human Rights and External Democratisation Agenda into EU Foreign Policy}

Driven by its own recent experience of transitioning from a socialist planned economy to a democratic liberal market, the Czech Republic took a clear interest in supporting transition policies in both the near and far abroad. In Prague's view, two inseparable elements lay at the core of any such transition: human rights and democracy. ${ }^{14}$ Over time, this understanding of political transition found institutional anchoring in the MFA's Department for Human Rights and Transformation Policies. In early 2005, the Czech government formulated its first concept of human rights and democracy promotion, introducing the term transition policy, which subsumed both policy dimensions. At the outset, Prague's transition policy was built around several clearly demarcated thematic and territorial priorities. Those themes included the strengthening of civil society in the target country, with a primary focus on furthering civic and political rights at the expense of other (e.g. economic, cultural and environmental) rights (Bílková and Matějková 2010a: 338). These so-called first generation rights were prioritised since they were seen as essential for establishing a democratic system of governance. Initially, the goal was to achieve these thematic goals in ten priority countries spanning the globe from Latin America (Cuba) to Europe (Belarus, Bosnia and Herzegovina, Kosovo, Moldova, Georgia, Serbia and Ukraine), the Middle East (Iraq) and Asia (Burma) (Bílková and Matějková 2010 b: 128). Over time, however, Prague came to realise that its transition experience was particularly useful in countries that were culturally, geographically, historically or otherwise similar, and the Czech transition policy concept was duly updated. Consequently, the Czech Republic turned its attention to Eastern Europe and the Western Balkans. Prague's preferred method for bilaterally promoting human rights and democratisation abroad was cooperation with

13 "Interview W," (Brussels: Permanent Representation of the Czech Republic to the European Union, 2010)

14 For a thorough analysis of the role that values and norms play in the Czech Republic's foreign policy, please refer to Waisová (2012). 
local non-governmental institutions, which were thought to understand the realities on the ground. Empowering civil society was, thus, seen as essential for the achievement of lasting democratic development.

It should come as no surprise, then, that in the lead-up to its EU Council presidency, the Czech Republic set out to advance its particular understanding of human rights and democracy promotion at EU level. These efforts were all the more predictable given Prague's general dissatisfaction with the Union's multilateral measures, which it regarded as uncoordinated, inconsistent and incoherent. ${ }^{15}$ To this end, the Czech government launched its "European Consensus on Democracy," an initiative that it would proceed to develop over the course of its presidency. This programme was modelled on the "European Consensus on Development," a plan which the European Parliament, the Council of the European Union and the European Commission had adopted in December 2005 and which comprehensively outlined the common principles and values behind the EU's development aims and efforts and stated concrete measures to be taken. ${ }^{16}$ Inspired by this blueprint, Prague attempted to solidify the Union's stance on democracy promotion in several stages: it first defined the constitutive elements of democracy and took steps to institutionalise democracy promotion activities within EU structures; it then set out an exhaustive list of policy instruments to be used to implement the plan. Alongside these efforts to introduce a new consensus about human rights and democracy promotion among individual member states, Prague also took a key practical step: it attempted to ensure the existence of Civil Society Forum, a civil society counterpart to the multilateral governmental discussions about the emerging Eastern Partnership.

While, as we have seen, in the two previously discussed cases, the Visegrád Group proved itself a valuable partner both in advancing Czech interests at supranational level and in negotiating specific policies, when it came to reforming the EU's external human rights and democratisation policy, the V4 added far less value. This can be explained as a result of the highly politically sensitive nature of notions such as human rights and democracy. As such, while practically all of the EU member states agreed on the need to observe human rights and maintained that a democratic system was the best system for this purpose, the questions of which human rights and what type of democracy were far more controversial. Combined with a more fundamental debate over whether human rights and democracy can and indeed should be promoted abroad, these questions spurred much disagreement among the EU member states when faced with

15 "Interview B," (Prague: Ministry of Foreign Affairs, 2010)

16 "The European Consensus on Development: Joint Statement by the Council and the Representatives of the Governments of the Member States Meeting within the Council, the European Parliament and the Commission on European Union Development Policy: 'The European Consensus'," available at http://eur-lex.europa.eu/legal-content/EN/TXT/PDF/?uri=CELEX:42006X0224(01)\&from=en (accessed 14 November 2016) 
the Czech Republic's position. Moreover, these discussions transcended the traditional V4/non-V4 dichotomy, forcing the Czech Republic to abandon its custom of first approaching Visegrád Group for support. Instead, Prague set out to establish a more diverse coalition of like-minded countries. While the Czech representatives in Brussels made some headway promoting the country's transition politics at EU level, no European Consensus on Democracy has been adopted until the present day, speaking directly to the controversial nature of the concept of democracy. With regard to the Civil Society Forum, the Czech Republic was somewhat more successful as this indeed became an inseparable element of the Eastern Partnership, albeit in a much weaker form than the Czech Republic initially proposed (Neuman 2015, pp. 236-246).

\section{Conclusion}

This contribution belongs to an ever-growing body of scholarship on the rotating EU Council presidency. More specifically, it has asked whether sub-regional integration projects such as the Visegrád Group can be understood as vehicles for pursuing one member's national interests while it stands at the European Union's helm. As such, this study has recognised Tallberg's claim that while an EU member state must observe the rules related to (among other things) neutrality during its Council presidency, both the period preceding that presidency and the presidency itself present the state with an opportunity to (at least partially) shape the EU's agenda and - by extension - its policies. Keeping this in mind, I have hypothesised that relying on sub-regional integration partners may well enable the EU Council presidency to maintain a smokescreen of neutrality while simultaneously pursuing its national interests.

This hypothesis has also been tested using the case of the first EU Council presidency of a Visegrád Group member, that is, the Czech Republic's presidency in the first semester of 2009. Assessing three specific policy areas - the reinvention of the EU Eastern neighbourhood policy; the strengthening of EU energy security; and the incorporation of a stronger human rights and external democratisation agenda into EU foreign policy - this empirical study has revealed a mixed picture. While in the first two instances, the Visegrád Group played an indispensable role in establishing and promoting the Czech Republic's national preference, this was not the case with regard to the Czech Republic's position on the European Union's external human rights and democratisation policy. The same pattern also holds true for the negotiation of specific policies at EU level: while the V4 was the Czech Republic's first target in establishing a coalition to support the launch of the Eastern Partnership and the promotion of energy security through diversified suppliers, routes and resources, the V4 did not exhibit much agency in the negotiation of the "Consensus on Democracy" and Civil Society Forum. Furthermore, these case studies also show that the Czech 
Republic realised the V4's potentially limited impact, and as such, took a multi-vectored approach to promoting its preferences at EU level. In other words, we can observe two parallel processes: on the one hand, the Czech Republic did indeed use the Visegrád Group as a vehicle for promoting its own interests in Brussels during its Council presidency in 2009; on the other, it did not give up on the option of fostering broader coalitions and nor did it shy away from pursuing its preferences more overtly at times. As such, to a greater or lesser extent, Prague compromised the neutrality rule associated with the Council presidency.

Overall, then, this study has confirmed the potential of the Visegrád Group to serve as a vehicle for furthering the national preferences of one member state while it holds the rotating EU Council presidency. Even so, whether or not this potential is fully realised will depend primarily on the degree to which the interests of the four Visegrád countries converge. Once again, this highlights the importance of treating the V4 not as a homogeneous group, but as an intergovernmental entity of four member states with - at times - diverging interests vis-à-vis further EU integration.

\section{References}

de Bassompierre, G. (1988): Changing the Guard in Brussels: An Insider's View of the EC Presidency (New York, Praeger).

Bílková, V. \& Matějková, Š. (2010a): Human Rights in the Czech Foreign Policy, in Kořan, M. (ed) (2010) Czech Foreign Policy in 2007-2009: Analysis (Prague, Institute of International Relations).

Bílková, V. \& Matějková, Š. (2010 b): Šíření demokracie jako národní zájem? Legitimizace české transformační politiky, in Drulák, P. \& Horký, O. (2010) Hledání českých zájmů: Obchod, lidská práva a mezinárodní rozvoj (Praha, Ústav mezinárodních vztahů).

Dangerfield, M. (2008): The Visegrád Group in the Expanded European Union: From Preaccession to Postaccession Cooperation, East European Politics and Societies, 22, 3.

Elgström, O. (2006): The Presidency: The Role(s) of the Chair in European Union Negotiations, The Hague Journal of Diplomacy, $1,2$.

Falkowski, M. (2003): Visegrad in the EU - Common vs. Individual Approach?, in Gyárfášová, O. (ed) (2003) Visegrad Citizens on the Doorstep of European Union (Bratislava, Institute for Public Affairs).

Gyárfášová, O. (2003): How Do We See Each Other? Mutual Perceptions of the Visegrad Citizens, in Gyárfášová O. (ed) (2003): Visegrad Citizens on the Doorstep of European Union (Bratislava, Institute for Public Affairs).

Heyes-Renshaw, F. \& Wallace, H. (1997): The Council of Ministers (New York, St. Martin's). 
Kořan, M. (2010): The Visegrad Cooperation, Poland, Slovakia and Austria in the Czech Foreign Policy, in Kořan, M. et al. (eds) (2010): Czech Foreign Policy in 2007-2009: Analysis (Prague, Institute of International Relations).

Kratochvíl, P. (2007): New EU Members and the ENP: Different Agendas, Different Strategies, Intereconomics, 4.

Neuman, M. (2010): EU-Russian Energy Relations after the 2004/2007 EU Enlargement: An EU Perspective, Journal of Contemporary European Studies, 18 (3).

Neuman, M. (2015): Too Small to Make an Impact? The Czech Republic's Influence on the European Union's Foreign Policy (Frankfurt am Main, Peter Lang).

Nosko, A., Orban, A., Paczynski, W., Černoch, F. \& Jaroš, J. (2010): Energy Security, in Visegrad Security Cooperation Initiative (Bratislava, Slovak Atlantic Commission).

Princen, S. (2007): Agenda-Setting in the European Union: A Theoretical Exploration and Agenda for Research. Journal of European Public Policy (14) 1.

Schalk, J., Torenvlied, R., Weesie, J. \& Stokman, F. (2007): The Power of the Presidency in EU Council Decision-Making, European Union Politics 8 (2).

Schneider, J. (2008): Project Summary: Central European Contribution to the Eastern Policy of the EU (Prague, Prague Security Studies Institute).

Schout, A. (1998): The Presidency as Juggler: Managing Conflicting Expectations, Eipascope, 2.

Stř́tecký, V. (2008): Focusing Eastwards: The ENP from the German to Czech EU Presidencies, in Nikolov, K. Y. (ed) (2008) The European Neighbourhood Policy: Time to Deliver (Sofia, Bulgarian European Community Studies Association).

Tallberg, J. (2003): The Agenda-Shaping Powers of the EU Council Presidency, Journal of European Public Policy, 10, 1.

Vondra, A. (2007): Solidarity as a Cornerstone of the EU Energy Policy, in Vilnius Energy Security Conference: Responsible Energy for Responsible Partners, Vilnius, 11 October 2007.

Waisová, Š. (2011): Regional Cooperation in Central Europe and Beyond: The Czech Republic as a Member of Regional Organizations, in Cabada, L. \& Waisová, Š. (eds) (2011) Czechoslovakia and the Czech Republic in World Politics (Plymuth, Lexington Books)

Waisová, Š. (2012): The Burden of Choice: Czech Foreign Policy between Principles and Interests (Frankfurt am Main, Peter Lang)

Marek Neuman is Assistant Professor at Department of International Relations and International Organization, Faculty of Arts, University of Groningen. E-mail: m.neuman@rug.nl. 